\title{
Expression profile of CADM1 and CADM4 in triple negative breast cancer with primary systemic therapy
}

\author{
YASUYUKI KANKE ${ }^{1}$, MOTONOBU SAITO ${ }^{1}$, NORIKO ABE ${ }^{2}$, KATSUHARU SAITO $^{1}$, AKITERU GOTO ${ }^{3}$, \\ TOHRU OHTAKE ${ }^{2}$, YOSHINORI MURAKAMI ${ }^{4}$ and KOJI KONO ${ }^{1}$
}

\begin{abstract}
Departments of ${ }^{1}$ Gastrointestinal Tract Surgery and ${ }^{2}$ Breast Surgery, Fukushima Medical University
School of Medicine, Fukushima, Fukushima 960-1295; ${ }^{3}$ Department of Cellular and Organ Pathology, Akita University Graduate School of Medicine, Akita, Akita 010-8543; ${ }^{4}$ Division of Molecular Pathology,

The Institute of Medical Science, The University of Tokyo, Tokyo 108-8639, Japan
\end{abstract}

Received February 16, 2018; Accepted October 26, 2018

DOI: $10.3892 / \mathrm{ol} .2018 .9727$

\begin{abstract}
Triple negative breast cancer (TNBC) is defined by a lack of ER, PgR, and HER 2 expression, and to date there have been no significant advances in treatment by targeted therapies against those molecules. Therefore, primary systemic therapy (PST) followed by surgery is the standard therapy for patients with advanced TNBC. According to gene expression analysis, TNBC has a distinct profile when compared with non-TNBC, suggesting that a unique gene affects the treatment efficacy of PST. Cell adhesion molecule (CADM) genes encode an immunoglobulin superfamily molecule involved in cell-to-cell adhesion in a variety of human epithelial cells. While it has been reported that inactivation of CADM1 and CADM4 serves a pivotal role in the progression of breast cancer, a full analysis has not been completed for TNBC. Previous studies have reported that CADM1 and CADM4 expression is less likely to be decreased in TNBC than in non-TNBC. In the present study, CADM1 and CADM4 expression was evaluated in patients with TNBC who had received PST. The present study revealed that loss or weak expression of CADM1 was frequently observed in non-pathological complete response patients. Furthermore, while the majority of TNBC cases exhibited high CADM1 expression, a small number of cases exhibited low CADM1 expression and low therapeutic response of PST for TNBC. These results suggest that CADM1 has a pivotal role in anti-PST efficacy in patients with TNBC.
\end{abstract}

Correspondence to: Dr Motonobu Saito, Department of Gastrointestinal Tract Surgery, Fukushima Medical University School of Medicine, 1 Hikarigaoka, Fukushima, Fukushima 960-1295, Japan E-mail: moto@fmu.ac.jp

Key words: CADM1, CADM4, triple negative breast cancer, primary systemic therapy

\section{Introduction}

Primary systemic therapy (PST) followed by surgery is a standard therapy for advanced breast cancer, including triple-negative breast cancer (TNBC) (1-3). Since patients with TNBC, which is used as a surrogate term for basal-like breast cancer subtypes, lack expression of estrogen receptor (ER), progesterone receptor (PgR), and human epidermal growth factor receptor 2 (HER2), no significant advances have yet been made regarding therapies for treating TNBC patients. Therefore, TNBC remains a deadly type of breast cancer, and further study is required to fully understand it. According to previously-reported gene expression analyses, TNBC has a distinct profile with non-TNBC $(4,5)$ and a heterogeneous tumor (6). This heterogeneity could be associated with the therapeutic response of PST for TNBC; however, the association between gene expression and PST response is still unknown.

Cell adhesion molecule (CADM) genes encode an immunoglobulin superfamily molecule and protect against malignant conversion and metastasis by maintaining cell-cell adhesion in epithelia $(7,8)$. Expression of CADM1 located on chromosome 11q23.2 was preferentially lost in invasive lesions compared to non-invasive lesions of lung adenocarcinoma (9). Several studies have also demonstrated that CADM1 is frequently inactivated in various cancers, including breast cancer (10-14). By using primary breast cancer specimens and breast cancer cell lines, loss of CADM1 and 4.1B expression has been reported to be associated with the development and progression of breast cancer, especially in invasion and metastasis (15). Therefore, CADM1 works as a tumor suppressor gene in non-small cell lung cancer as well as breast cancer (16). CADM4, which is located on chromosome 19q13.31, also works as a tumor suppressor gene in renal clear cell carcinoma, colon cancer, and breast cancer (17-19). We recently demonstrated that CADM1 and CADM4 were less frequently inactivated in TNBC than in non-TNBC (20). Our results that the roles of CADM1 and CADM4 in TNBC are different than their in non-TNBC, and those genes may therefore be associated with the therapeutic response to PST for TNBC. 
The efficacy of PST for TNBC can be improved by further understanding of the molecular expression levels in individual tumors. Herein, we report the evaluation of CADM1 and CADM4 expression in TNBC patients who had received PST, and try to define a therapeutic response based on CADM1 and CADM4 expression levels.

\section{Materials and methods}

Patients and tissue samples. Primary invasive breast cancer samples were obtained from patients who had undergone surgical resections with chemotherapy prior to surgery at the Department of Breast Surgery in Fukushima Medical University Hospital, Fukushima, Japan. This cohort consisted of 16 patients who had been enrolled consecutively at the time of surgery between Jan, 2006 and Dec, 2012. All 16 patients had received a core needle biopsy $(\mathrm{CNB})$ at the initial histological diagnosis, after which they received PST; 5-fluorouracil, epirubicin, and cyclophosphamide (FEC) or FEC followed by paclitaxel (PTX) or docetaxel (DTX). The clinical therapeutic response to PST was evaluated using the Response Evaluation Criteria In Solid Tumors (RECIST) guidelines (21), and each case was categorized as complete response (CR), partial response (PR), stable disease $(\mathrm{SD})$, or progressive disease (PD). After surgical resection, therapeutic response to PST was evaluated histologically, and the patients were divided into pathological $\mathrm{CR}(\mathrm{pCR})$ or non-pCR groups.

Detailed backgrounds of each tissue donor, including age, sex, clinical staging, and hormone status, were collected. Tumor histopathology was classified according to the Union for International Cancer Control (UICC) TNM classification (the 7th classification) (22). Written informed consent was obtained from all patients, and the study was approved by the Institutional Review Board of Fukushima Medical University, Japan.

IHC staining. IHC staining for CADM1 and CADM4 was performed by same method as previously described (20). The breast cancer tissue samples were fixed in $10 \%$ formalin, embedded in paraffin, cut into $4-\mu \mathrm{m}$ sections and stained with hematoxylin and eosin (H\&E) and other primary antibodies. Rabbit polyclonal antibodies against CADM1 (1:500, C-18, generated by the Division of Molecular Pathology, Institute of Medical Science, The University of Tokyo) and CADM4 (1:500, Bc-2, generated by the Division of Molecular Pathology, Institute of Medical Science, The University of Tokyo, Tokyo, Japan) were used as described previously (17). The antibodies used for IHC staining were as follows: Anti-ER (1:500, cat. no. MA5-13191; Dako; Agilent Technologies GmbH, Waldbronn, Germany); and anti-PgR (1:500, cat. no., MA5-12581; Dako; Agilent Technologies GmbH). For HER 2 status, the Histofine ${ }^{\circledR}$ Simple Stain HER2 mono assay kit was used (cat. no. 427041; Nichirei Biosciences, Inc., Tokyo, Japan). Analyses of ER, PgR, and HER2 were performed using IHC staining according to the manufacturer's protocol. The sections were deparaffinized in xylene, and hydrated using a graded series of ethanol at room temperature. Subsequently, the sections were washed three times in PBS and endogenous peroxidase was blocked with $0.3 \%$ in methanol for $30 \mathrm{~min}$ at room temperature. Antigens were retrieved by autoclaving the sections on slides in $0.01 \mathrm{M} \mathrm{pH} 6.0$ citrate buffer for $10 \mathrm{~min}$ at $121^{\circ} \mathrm{C}$. Subsequent to washing in PBS, the sections were incubated in primary antibody overnight at $4^{\circ} \mathrm{C}$. A further wash in PBS was followed by treatment with the secondary antibody [K1491, Dako EnVision kit/horseradish peroxidase (HRP)] for $30 \mathrm{~min}$ at room temperature and diaminobenzidine (K1491, Dako EnVision kit/HRP) was used for staining detection (both from Dako: Agilent Technologies GmbH). Finally, the sections were counterstained with hematoxylin. Expression of these proteins was evaluated using optical microscopy (BX43; Olympus Corporation, Tokyo, Japan) at x400 magnification.

Assessment of IHC staining. Stain signals of CADM1 and CADM4 protein levels were detected in the membranes in normal mammary epithelial cells. Cytoplasmic immunoreactivity without membrane staining was defined as aberrant expression. Membranous staining of CADM1 or CADM4 was evaluated by calculating the percentage of cancer cells with membrane expression in the entire area of invasive and non-invasive lesions. The tumors or lesions were then scored as previously described (15); those with scores of 1 (11-30\% cells with membrane expression), 2 (31-60\%) or 3 (61-100\%) were defined as positive staining for CADM1 or CADM4 expression, and those with a score of $0(0-10 \%)$ were defined as negative staining. ER, PgR and HER2 expression levels were evaluated semi-quantitatively, with scores representing the ratio of the number of positive staining cells compared with negative cells, as previously described (23). Assessment of the staining was performed blindly by two independent investigators, including an experienced pathologist (Dr Akiteru Goto from Akita University, who was the pathologist, and Dr Motonobu Saito from Fukushima Medical University). Any disagreements between the two investigators was resolved by discussion.

Statistical analysis. Fisher's exact test was performed by GraphPad Prism 6 software (GraphPad Software, Inc., La Jolla, CA, USA). $\mathrm{P}<0.05$ was considered to indicate a statistically significant difference.

\section{Results}

Patient characteristics. The clinical characteristics of the 16 TNBC patients are shown in Table I. All patients were female with ages ranging from 33 to 78 years (mean 49.1 years), and had been diagnosed as having invasive ductal carcinoma. The patients included four stage IIA, nine stage IIB, and three stage IIIB patients. The cases received one of the following treatments: PST as FEC only $(n=2)$; FEC followed by PTX $(n=7)$ or FEC followed by DTX $(n=7)$. The clinical tumor responses to PST as evaluated by RECIST were CR $(n=4)$, PR $(n=10), \operatorname{SD}(n=1)$, and PD $(n=1)$. The histological diagnoses in the surgical specimens were pCR $(n=3)$ and non-pCR $(n=13)$.

Associations between CADM1 and CADM4 expression and clinicopathological factors in TNBC. We evaluated CADM1 and CADM4 expression by IHC staining in surgical or CNB 
Table I. Clinicophathological characteristics of patients with PST triple negative breast cancer.

\begin{tabular}{|c|c|}
\hline Characteristics & $\mathrm{n}(\%)$ \\
\hline \multicolumn{2}{|l|}{ Age (years) } \\
\hline Mean & 49 \\
\hline Range & $33-78$ \\
\hline \multicolumn{2}{|l|}{ Sex } \\
\hline Female & $16(100)$ \\
\hline \multicolumn{2}{|l|}{ Histological type } \\
\hline Invasive carcinoma of no special type & $16(100)$ \\
\hline \multicolumn{2}{|l|}{ TNM stage at initial diagnosis (22) } \\
\hline I & 0 \\
\hline IIA & $4(25)$ \\
\hline IIB & $9(56)$ \\
\hline IIIA & 0 \\
\hline IIIB & $3(19)$ \\
\hline \multicolumn{2}{|l|}{ PST regimens } \\
\hline FEC & $2(13)$ \\
\hline FEC+PTX & $7(44)$ \\
\hline FEC+DTX & $7(44)$ \\
\hline \multicolumn{2}{|l|}{ Clinical tumor response ${ }^{a}$} \\
\hline $\mathrm{CR}$ & $4(25)$ \\
\hline PR & $10(63)$ \\
\hline SD & $1(6)$ \\
\hline PD & $1(6)$ \\
\hline \multicolumn{2}{|l|}{ PST effect } \\
\hline $\mathrm{pCR}$ & $3(19)$ \\
\hline Non-pCR & $13(81)$ \\
\hline \multicolumn{2}{|c|}{$\begin{array}{l}\text { aClinical therapeutic response to PST was evaluated using the } \\
\text { Response Evaluation Criteria In Solid Tumors (RECIST) guidelines. } \\
\text { FEC, 5-fluorouracil, epirubicin, and cyclophosphamide; PTX, pacli- } \\
\text { taxel; DTX, docetaxel; CR, complete response; PR, partial response; } \\
\text { SD, stable disease; PD, progressive disease; PST, primary systemic } \\
\text { therapy; pCR, pathological complete response. }\end{array}$} \\
\hline
\end{tabular}

specimens from three pCR and 11 non-pCR TNBC patients who received PST (Table II). While surgical specimens are usually used for IHC staining to measure protein expression, the usefulness of IHC staining with CNB specimens at the initial diagnosis is still unknown. Therefore, we firstly compared CADM1 and CADM4 expression between the CNB and surgical specimens. Among the 13 non-pCR cases in our cohort, nine could be used in this comparison, seven of which had an identical staining intensity score for CADM1 and CADM4 between CNB and surgical specimens (non-pCR 3, non-pCR 4, non-pCR 5, non-pCR 6, non-pCR7, non-pCR 12, and non-pCR 13 cases) (Fig. 1A). Two cases (non-pCR 1 and non-pCR 2 Cases) showed weaker staining intensity in the CNB specimen (score 1) than in the surgical specimen (scores 2 and 3).

Next, we assessed the impact of CADM1 and CADM4 expression on therapeutic responses. Among the 13 non-pCR cases, one exhibited negative CADM1 expression and two showed weak positive CADM1 expression (score 1) in the surgical specimens, while two cases showed weak positive CADM4 expression (score 1) (Table II). Since there were no available resected tumor specimens for IHC staining in three pCR cases, the evaluation of therapeutic responses according to CADM1 and CADM4 expression levels between non-pCR and pCR cases was impossible. Therefore, the CNB specimens were used for this comparison (Fig. 1B). While all three pCR cases showed strong positive CADM1 expression (score 2 and 3), two cases showed weak positive CADM1 expression (score 1) and 7 cases showed strong CADM1 expression (score 2 and 3) in non-pCR cases $(\mathrm{P}=1)$ (Table III). On the other hand, while one weak positive (score 1) and one strong positive (score 2 and 3) CADM4 expression in $\mathrm{pCR}$ cases, two cases showed weak positive CADM1 expression (score 1) and 7 cases showed strong CADM4 expression (score 2 and 3) in non-pCR cases $(\mathrm{P}=0.49)$. Although we have expected that loss of or weak positive CADM1 or CADM4 expression may affect therapeutic response, our results lead to no common tendencies.

\section{Discussion}

Inactivated expression of CADM1 and CADM4 has been correlated with local invasion, lymph node metastasis, lymphovascular invasion (15) and poor prognosis in breast cancer $(18,24)$. Therefore, it is considered that CADM1 and CADM4 suppress tumor development in cases of breast cancer. However, we previously evaluated CADM1 and CADM4 expression in breast cancer and found that those expression levels were less frequently decreased in TNBC cases than in non-TNBC cases (20). In the present study, we investigated further into CADM1 and CADM4 expression levels in both CNB and surgical specimens in TNBC patients who received PST. This analysis allowed us to predict therapeutic efficacy using the pair samples of pre- and post-PST. As a result, we revealed that loss or weak positive expression of CADM1 was frequently observed in non-pCR patients. That loss of CADM1 and CADM4 was less associated with tumorigenesis in the TNBC cases than with that in the non-TNBC cases suggests that TNBC is a unique subtype of breast cancer, which requires further examination.

Approximately $80 \%$ of TNBC is classified as basal-like breast cancer, which is one of the intrinsic subtypes as categorized by the gene expression profile $(4,5)$. Basal-like breast cancer is different from other intrinsic subtypes, such as luminal A, luminal $\mathrm{B}$, and HER2 overexpressing breast cancer. Therefore, breast cancer should be considered to be a heterogeneous disease, and TNBC should also be considered to be a unique subtype of breast cancer. In addition, TNBC exhibits a high level of genomic instability, resulting in a high level of intratumor heterogeneity (6), and is categorized into several distinct subtypes $(25,26)$. Recently, next-generation sequencing (NGS) has progressed significantly and, by using the NGS method, we have revealed gene aberration profiles of breast tumors in adolescent and young adult females (27). Noteworthy, the NGS has also revealed intratumor heterogeneity and accelerated the understanding of clonal evolution in cancer $(28,29)$. Phylogenic trees, which were constructed based on clonal (truncal) and subclonal (branched) mutation analyses, uncovered highly important issues regarding 
Table II. Comparison of CADM1 and CADM4 expression at initial diagnosis or surgery in non-pCR and pCR TNBC patients.

\begin{tabular}{|c|c|c|c|c|c|c|}
\hline Case & $\begin{array}{c}\text { Age } \\
\text { (years) }\end{array}$ & $\begin{array}{c}\text { Stage [initial } \\
\text { diagnosis, (22)] }\end{array}$ & PST & Specimen & CADM1 score & CADM4 score \\
\hline Non-pCR 1 & 45 & IIB & FEC+DTX & $\begin{array}{l}\text { CNB } \\
\text { surgery }\end{array}$ & $\begin{array}{l}1 \\
2 \text { and } 3\end{array}$ & $\begin{array}{l}1 \\
2 \text { and } 3\end{array}$ \\
\hline Non-pCR 2 & 61 & IIA & FEC+PTX & $\begin{array}{l}\text { CNB } \\
\text { surgery }\end{array}$ & $\begin{array}{l}1 \\
2 \text { and } 3\end{array}$ & $\begin{array}{l}1 \\
2 \text { and } 3\end{array}$ \\
\hline Non-pCR 3 & 34 & IIA & FEC & $\begin{array}{l}\text { CNB } \\
\text { Surgery }\end{array}$ & $\begin{array}{l}2 \text { and } 3 \\
2 \text { and } 3\end{array}$ & $\begin{array}{l}2 \text { and } 3 \\
2 \text { and } 3\end{array}$ \\
\hline Non-pCR 4 & 44 & IIB & FEC+DTX & $\begin{array}{l}\text { CNB } \\
\text { Surgery }\end{array}$ & $\begin{array}{l}2 \text { and } 3 \\
2 \text { and } 3\end{array}$ & $\begin{array}{l}2 \text { and } 3 \\
2 \text { and } 3\end{array}$ \\
\hline Non-pCR 5 & 46 & IIA & FEC+DTX & $\begin{array}{l}\text { CNB } \\
\text { Surgery }\end{array}$ & $\begin{array}{l}2 \text { and } 3 \\
2 \text { and } 3\end{array}$ & $\begin{array}{l}2 \text { and } 3 \\
2 \text { and } 3\end{array}$ \\
\hline Non-pCR 6 & 54 & IIB & $\mathrm{FEC}+\mathrm{PTX}$ & $\begin{array}{l}\text { CNB } \\
\text { Surgery }\end{array}$ & $\begin{array}{l}2 \text { and } 3 \\
2 \text { and } 3\end{array}$ & $\begin{array}{l}2 \text { and } 3 \\
2 \text { and } 3\end{array}$ \\
\hline Non-pCR 7 & 58 & IIB & FEC+PTX & $\begin{array}{l}\text { CNB } \\
\text { Surgery }\end{array}$ & $\begin{array}{l}2 \text { and } 3 \\
2 \text { and } 3\end{array}$ & $\begin{array}{l}2 \text { and } 3 \\
2 \text { and } 3\end{array}$ \\
\hline Non-pCR 8 & 44 & IIIB & FEC & $\begin{array}{l}\text { CNB } \\
\text { Surgery }\end{array}$ & $\begin{array}{l}\text { NA } \\
0\end{array}$ & $\begin{array}{l}\text { NA } \\
1\end{array}$ \\
\hline Non-pCR 9 & 33 & IIB & FEC+DTX & $\begin{array}{l}\text { CNB } \\
\text { Surgery }\end{array}$ & $\begin{array}{l}\text { NA } \\
1\end{array}$ & $\begin{array}{l}\text { NA } \\
2 \text { and } 3\end{array}$ \\
\hline Non-pCR 10 & 78 & IIIB & FEC+DTX & $\begin{array}{l}\text { CNB } \\
\text { Surgery }\end{array}$ & $\begin{array}{l}\text { NA } \\
1\end{array}$ & $\begin{array}{l}\text { NA } \\
2 \text { and } 3\end{array}$ \\
\hline Non-pCR 11 & 51 & IIIB & FEC+DTX & $\begin{array}{l}\text { CNB } \\
\text { Surgery }\end{array}$ & $\begin{array}{l}\text { NA } \\
2 \text { and } 3\end{array}$ & $\begin{array}{l}\text { NA } \\
1\end{array}$ \\
\hline Non-pCR 12 & 45 & IIA & FEC+PTX & $\begin{array}{l}\text { CNB } \\
\text { Surgery }\end{array}$ & $\begin{array}{l}2 \text { and } 3 \\
2 \text { and } 3\end{array}$ & $\begin{array}{l}2 \text { and } 3 \\
2 \text { and } 3\end{array}$ \\
\hline Non-pCR 13 & 52 & IIB & FEC+PTX & $\begin{array}{l}\text { CNB } \\
\text { Surgery }\end{array}$ & $\begin{array}{l}2 \text { and } 3 \\
2 \text { and } 3\end{array}$ & $\begin{array}{l}2 \text { and } 3 \\
2 \text { and } 3\end{array}$ \\
\hline pCR 1 & 40 & IIB & $\mathrm{FEC}+\mathrm{PTX}$ & $\begin{array}{l}\text { CNB } \\
\text { Surgery }\end{array}$ & $\begin{array}{l}2 \text { and } 3 \\
\text { NA }\end{array}$ & $\begin{array}{l}1 \\
\text { NA }\end{array}$ \\
\hline pCR 2 & 50 & IIB & $\mathrm{FEC}+\mathrm{PTX}$ & $\begin{array}{l}\text { CNB } \\
\text { Surgery }\end{array}$ & $\begin{array}{l}2 \text { and } 3 \\
\text { NA }\end{array}$ & $\begin{array}{l}2 \text { and } 3 \\
\text { NA }\end{array}$ \\
\hline pCR 3 & 51 & IIB & FEC+DTX & $\begin{array}{l}\text { CNB } \\
\text { Surgery }\end{array}$ & $\begin{array}{l}2 \text { and } 3 \\
\text { NA }\end{array}$ & $\begin{array}{l}0 \\
\text { NA }\end{array}$ \\
\hline
\end{tabular}

FEC, 5-fluorouracil, epirubicin, and cyclophosphamide; PTX, paclitaxel; DTX, docetaxel; CNB, core needle biopsy; NA, not applicable; TNBC, triple negative breast cancer; pCR, pathological complete response.

malignant tumors. For example, genomic sequencing from different regions of a tumor may sometimes lead to different mutation profiles. When this situation occurs in driver genes, it results in different treatment strategy selection (30). Protein expression may also have the same issue, suggesting that it is not possible to analyze data without considering intratumoral heterogeneity. Therefore, we compared CADM1 and CADM4 expression levels between CNB and surgical specimens. Ultrasound-guided CNB was performed to obtain breast cancer tissue samples for pathological diagnosis at the initial diagnosis. After PST, the tumor tissue was resected and compared with a CNB specimen. In our study, both CADM1 and CADM4 expression levels in the CNB specimens were almost consistent with those in the surgical specimens.
The present study has several limitations. First, it is a retrospective study with a small sample size. Second, although we suggest that CADM1 has an anti-PST role in TNBC, no biological functions are proposed. Further large scale and functional studies are required.

\section{Acknowledgements}

Not applicable.

\section{Funding}

This work was supported by a research grant from Japanese Society of Strategies for Cancer Research and Therapy (JSCT) and the JSPS KAKENHI grant no. 17k10556. 
Table III. Comparison of CADM1 and CADM4 expression at initial diagnosis in non-pCR and pCR TNBC patients.

\begin{tabular}{|c|c|c|c|c|c|c|c|}
\hline \multirow[b]{2}{*}{ Case } & \multicolumn{3}{|c|}{ CADM1 score in CNB specimen } & \multirow[b]{2}{*}{ Case } & \multicolumn{3}{|c|}{ CADM4 score in CNB specimen } \\
\hline & 1 & 2 and 3 & P-value ${ }^{a}$ & & 1 & 2 and 3 & P-value ${ }^{a}$ \\
\hline non-pCR $(\mathrm{n}=9)$ & 2 & 7 & 1.00 & non-pCR $(\mathrm{n}=9)$ & 2 & 7 & 0.49 \\
\hline $\mathrm{pCR}(\mathrm{n}=3)$ & 0 & 3 & & $\mathrm{pCR}(\mathrm{n}=2)$ & 1 & 1 & \\
\hline
\end{tabular}

TNBC, triple negative breast cancer; pCR, pathological complete response; CNB, core needle biopsy. ${ }^{a}$ Fisher's exact test.

A

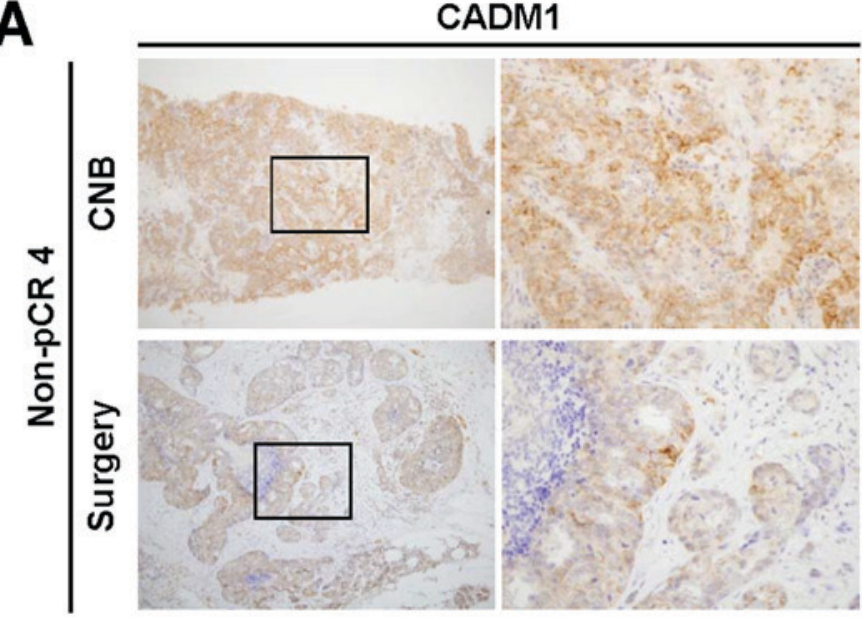

B

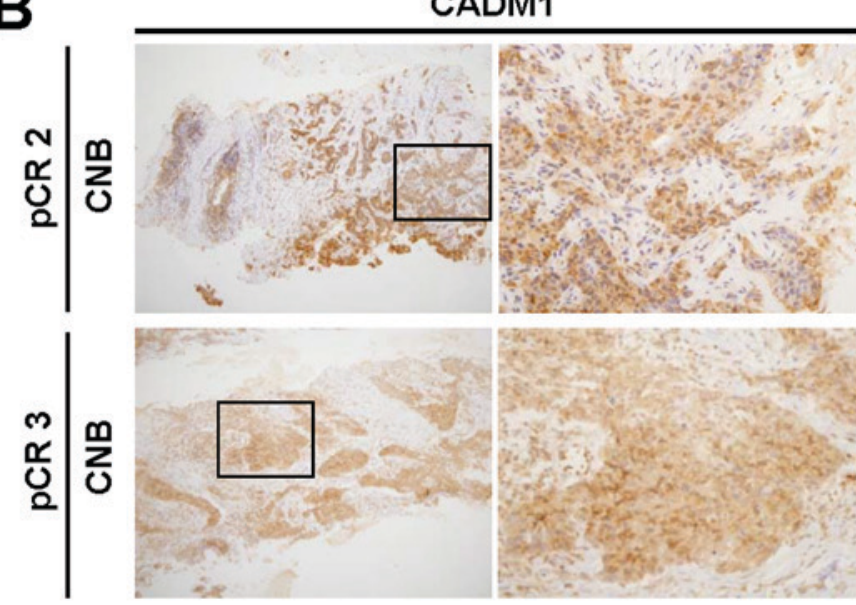

CADM4

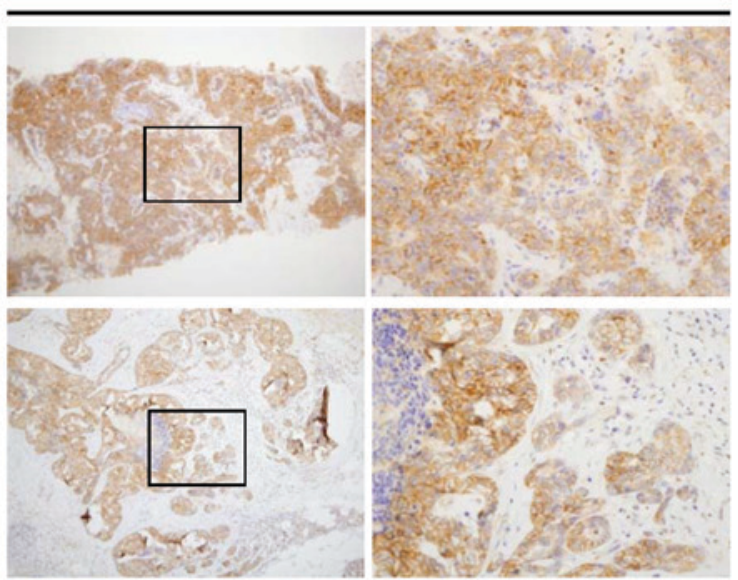

CADM4

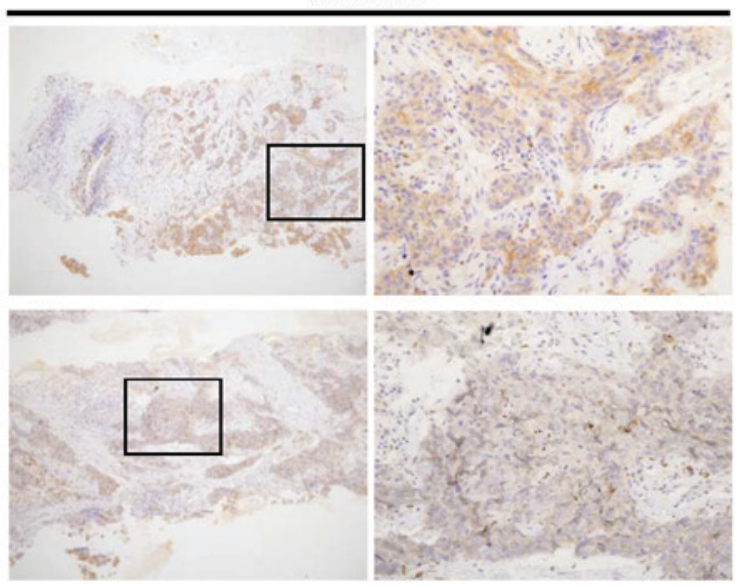

Figure 1. Representative images of CADM1 and CADM4 immunohistochemical staining of CNB and surgical specimens. (A) A non-pCR case with both positive CADM1 and CADM4 staining in CNB and surgical specimens. (B) A pCR case (pCR 2) with positive CADM1 and positive CADM4 staining in CNB (upper four panels). A pCR case (pCR 3) with positive CADM1 and negative CADM4 staining in CNB (lower four panels). Left low magnification (x100) and right high magnification $(\mathrm{x} 400)$ panels are shown. A high magnification image $(\mathrm{x} 400)$ of the region in the black rectangle of the left panel is presented in the right panel. pCR, pathological complete response, CNB; core needle biopsy; CADM, cell adhesion molecule.

\section{Availability of data and materials}

All data generated or analyzed during this study are included within the manuscript.

\section{Authors' contributions}

YK, KK and MS designed the study. YK, MS, KS, AG, and YM performed immunohistochemical staining and analyzed the data. NA and TO collected clinical information. YK, MS and $\mathrm{KK}$ wrote the manuscript. All authors have read and approved the final manuscript.

\section{Ethics approval and consent to participate}

Written informed consent was obtained from all patients, and the Institutional Review Board of Fukushima Medical University, Japan approved the present study. Each patient 
provided written informed consent for the publication of any data and associated images.

\section{Patient consent for publication}

Not applicable.

\section{Competing interests}

The authors declare that they have no competing interests.

\section{References}

1. Berruti A, Generali D, Bertaglia V, Brizzi MP, Mele T, Dogliotti L, Bruzzi P and Bottini A: Intermediate endpoints of primary systemic therapy in breast cancer patients. J Natl Cancer Inst Monogr 2011: 142-146, 2011.

2. Berruti A, Generali D, Kaufmann M, Puztai L, Curigliano G, Aglietta M, Gianni L, Miller WR, Untch M, Sotiriou C, et al: International expert consensus on primary systemic therapy in the management of early breast cancer: Highlights of the Fourth Symposium on Primary Systemic Therapy in the Management of Operable Breast Cancer, Cremona, Italy (2010). J Natl Cancer Inst Monogr 2011: 147-151, 2011.

3. Gralow JR, Burstein HJ, Wood W, Hortobagyi GN, Gianni L, von Minckwitz G, Buzdar AU, Smith IE, Symmans WF, Singh B and Winer EP: Preoperative therapy in invasive breast cancer: Pathologic assessment and systemic therapy issues in operable disease. J Clin Oncol 26: 814-819, 2008.

4. Weigelt B, Baehner FL and Reis-Filho JS: The contribution of gene expression profiling to breast cancer classification, prognostication and prediction: A retrospective of the last decade. J Pathol 220: 263-280, 2010.

5. Sørlie T, Perou CM, Tibshirani R, Aas T, Geisler S, Johnsen H, Hastie T, Eisen MB, van de Rijn M, Jeffrey SS, et al: Gene expression patterns of breast carcinomas distinguish tumor subclasses with clinical implications. Proc Natl Acad Sci USA 98: 10869-10874, 2001.

6. Turner NC and Reis-Filho JS: Tackling the diversity of triple-negative breast cancer. Clin Cancer Res 19: 6380-6388, 2013.

7. Ito A, Ichiyanagi N, Ikeda Y, Hagiyama M, Inoue T, Kimura KB, Sakurai MA, Hamaguchi K and Murakami Y: Adhesion molecule CADM1 contributes to gap junctional communication among pancreatic islet $\alpha$-cells and prevents their excessive secretion of glucagon. Islets 4: 49-55, 2012.

8. Murakami Y: Functional cloning of a tumor suppressor gene, TSLC1, in human non-small cell lung cancer. Oncogene 21: 6936-6948, 2002.

9. Goto A, Niki T, Chi-Pin L, Matsubara D, Murakami Y, Funata N and Fukayama M: Loss of TSLC1 expression in lung adenocarcinoma: Relationships with histological subtypes, sex and prognostic significance. Cancer Sci 96: 480-486, 2005.

10. Hui AB, Lo KW, Kwong J, Lam EC, Chan SY, Chow LS, Chan AS, Teo PM and Huang DP: Epigenetic inactivation of TSLC1 gene in nasopharyngeal carcinoma. Mol Carcinog 38: 170-178, 2003.

11. Honda T, Tamura G, Waki T, Jin Z, Sato K, Motoyama T, Kawata S, Kimura W, Nishizuka S and Murakami Y: Hypermethylation of the TSLC1 gene promoter in primary gastric cancers and gastric cancer cell lines. Jpn J Cancer Res 93: 857-860, 2002.

12. Jansen M, Fukushima N, Rosty C, Walter K, Altink R, Heek TV, Hruban R, Offerhaus JG and Goggins M: Aberrant methylation of the 5' CpG island of TSLC1 is common in pancreatic ductal adenocarcinoma and is first manifest in high-grade PanlNs. Cancer Biol Ther 1: 293-296, 2002.

13. Fukuhara H, Kuramochi M, Fukami T, Kasahara K, Furuhata M, Nobukuni T, Maruyama T, Isogai K, Sekiya T, Shuin T, et al: Promoter methylation of TSLC1 and tumor suppression by its gene product in human prostate cancer. Jpn J Cancer Res 93: 605-609, 2002.

14. Steenbergen RD, Kramer D, Braakhuis BJ, Stern PL, Verheijen RH, Meijer CJ and Snijders PJ: TSLC1 gene silencing in cervical cancer cell lines and cervical neoplasia. J Natl Cancer Inst 96: 294-305, 2004
15. Takahashi Y, Iwai M, Kawai $T$, Arakawa A, Ito $T$, Sakurai-Yageta M, Ito A, Goto A, Saito M, Kasumi F and Murakami Y: Aberrant expression of tumor suppressors CADM1 and 4.1B in invasive lesions of primary breast cancer. Breast Cancer 19: 242-252, 2012.

16. Kuramochi M, Fukuhara H, Nobukuni T, Kanbe T, Maruyama T, Ghosh HP, Pletcher M, Isomura M, Onizuka M, Kitamura T, et al: TSLC1 is a tumor-suppressor gene in human non-small-cell lung cancer. Nat Genet 27: 427-430, 2001.

17. Nagata M, Sakurai-Yageta M, Yamada D, Goto A, Ito A, Fukuhara H, Kume H, Morikawa T, Fukayama M, Homma Y and Murakami Y: Aberrations of a cell adhesion molecule CADM4 in renal clear cell carcinoma. Int J Cancer 130: 1329-1337, 2012

18. Jang SM, Sim J, Han H, Ahn HI, Kim H, Yi K, Jun YJ, Rehman A, Chung MS, Jang K and Paik SS: Clinicopathological significance of CADM4 expression in invasive ductal carcinoma of the breast. J Clin Pathol 66: 681-686, 2013.

19. Jang SM, Han H, Jun YJ, Jang SH, Min KW, Sim J, Ahn HI, Lee KH, Jang KS and Paik SS: Clinicopathological significance of CADM4 expression, and its correlation with expression of E-cadherin and $\mathrm{Ki}-67$ in colorectal adenocarcinomas. J Clin Pathol 65: 902-906, 2012.

20. Saito M, Goto A, Abe N, Saito K, Maeda D, Ohtake T, Murakami Y and Takenoshita S: Decreased expression of CADM1 and CADM4 are associated with advanced stage breast cancer. Oncol Lett 15: 2401-2406, 2018

21. Eisenhauer EA, Therasse P, Bogaerts J, Schwartz LH, Sargent D, Ford R, Dancey J, Arbuck S, Gwyther S, Mooney M, et al: New response evaluation criteria in solid tumours: Revised RECIST guideline (version 1.1). Eur J Cancer 45: 228-247, 2009.

22. Sobin LH, Gospodarowicz $\mathrm{M}$ and Wittekind Ch (eds): International Union Against Cancer (UICC) TNM Classification of Malignant Tumors, 7th edition. Wiley-Blackwell, Oxford, UK, 2010.

23. Saito M, Matsuzaki M, Sakuma T, Katagata N, Watanabe F, Yamaguchi Y, Schetter AJ, Takenoshita S and Nomizu T: Clinicopathological study of non-palpable familial breast cancer detected by screening mammography and diagnosed as DCIS. Breast Cancer 21: 140-145, 2014.

24. Wikman H, Westphal L, Schmid F, Pollari S, Kropidlowski J, Sielaff-Frimpong B, Glatzel M, Matschke J, Westphal M, Iljin K, et al: Loss of CADM1 expression is associated with poor prognosis and brain metastasis in breast cancer patients. Oncotarget 5: 3076-3087, 2014.

25. Abramson VG, Lehmann BD, Ballinger TJ and Pietenpol JA: Subtyping of triple-negative breast cancer: Implications for therapy. Cancer 121: 8-16, 2015.

26. Abramson VG and Mayer IA: Molecular heterogeneity of triple negative breast cancer. Curr Breast Cancer Rep 6: 154-158, 2014.

27. Kanke Y, Shimomura A, Saito M, Honda T, Shiraishi K, Shimada Y, Watanabe R, Yoshida H, Yoshida M, Shimizu C, et al: Gene aberration profile of tumors of adolescent and young adult females. Oncotarget 9: 6228-6237, 2017.

28. Greaves M and Maley CC: Clonal evolution in cancer. Nature 481: 306-313, 2012.

29. Zhang J, Fujimoto J, Zhang J, Wedge DC, Song X, Zhang J, Seth S, Chow CW, Cao Y, Gumbs C, et al: Intratumor heterogeneity in localized lung adenocarcinomas delineated by multiregion sequencing. Science 346: 256-259, 2014.

30. de Bruin EC, McGranahan N, Mitter R, Salm M, Wedge DC, Yates L, Jamal-Hanjani M, Shafi S, Murugaesu N, Rowan AJ, et al: Spatial and temporal diversity in genomic instability processes defines lung cancer evolution. Science 346: 251-256, 2014.

This work is licensed under a Creative Commons Attribution-NonCommercial-NoDerivatives 4.0 International (CC BY-NC-ND 4.0) License. 